\title{
Cancer Incidence and Mortality in the Czech Republic
}

\section{Incidence a mortalita nádorových onemocnění v České republice}

\author{
Dusek L. ${ }^{1,2}$, Muzik J. ${ }^{1,2}$, Maluskova D. ${ }^{1}$, Majek O. ${ }^{1,2}$, PavlikT. ${ }^{1}$, Koptikova J. ${ }^{1}$, Melichar B. ${ }^{3}$, Büchler T. ${ }^{4}$, Finek J. ${ }^{5}$, \\ Cibula D. ${ }^{6}$, Babjuk M. ${ }^{7}$, Svoboda M. ${ }^{8}$, Vyzula R. ${ }^{8}$, Ryska A. ${ }^{9}$, Ryska M. ${ }^{10}$, Petera J. ${ }^{11}$, Abrahamova J. ${ }^{4}$ \\ 'Institute of Biostatistics and Analyses, Faculty of Medicine and Faculty of Science, Masaryk University, Brno \\ ${ }^{2}$ Institute of Health Information and Statistics of the Czech Republic, Prague \\ ${ }^{3}$ Department of Oncology, Palacký University Medical School and University Hospital, Olomouc \\ ${ }^{4}$ Department of Oncology, Thomayer Hospital, Prague \\ ${ }^{5}$ Department of Oncology and Radiotherapy, University Hospital, Pilsen \\ ${ }^{6}$ Gynaecological Oncologic Centre and $1{ }^{\text {st }}$ Faculty of Medicine, General University Hospital and Charles University, Prague \\ ${ }^{7}$ Department of Urology and $2^{\text {nd }}$ Faculty of Medicine, University Hospital Motol and Charles University, Prague \\ ${ }^{8}$ Department of Comprehensive Cancer Care, Masaryk Memorial Cancer Institute, Brno \\ ${ }^{9}$ The Fingerland Department of Pathology, Charles University Medical Faculty and University Hospital Hradec Králové \\ ${ }^{10}$ Department of Surgery, $2^{\text {nd }}$ Faculty of Medicine, Charles University and Cental Military Hospital, Prague \\ "Department of Oncology and Radiotherapy, Charles University Medical Faculty and University Hospital Hradec Králové
}

\begin{abstract}
Summary
Background: The Czech Republic ranks among the countries with the highest cancer burden in Europe as well as worldwide. The purpose of this study is to summarize long-term trends in the cancer burden and to provide up-to-date estimates of incidence and mortality rates after 2011. Data and Methods: The Czech National Cancer Registry (CNCR) was instituted in 1977 and contains information collected over a 34-year period of standardized registration covering $100 \%$ of cancer diagnoses within the entire Czech population. The CNCR analysis is supported by demographic data and by the Death Records Database. An overview of the epidemiology of malignant tumors in the Czech population is available on-line at www.svod.cz. Results: All neoplasms, including non-melanoma skin cancer, reached a crude incidence rate of almost 802 cases per 100,000 men and 681 cases per 100,000 women in 2011. The annual mortality rate exceeded 258 deaths per 100,000 individuals; in other words, more than 27,000 individuals die of cancer each year. The overall incidence of malignancies has increased with a growth index of $+27.6 \%$ during the last decade (2001-2011), while the mortality rate has been stabilized over the time span (growth index in 2001-2011: $-5.0 \%$ ). Consequently, the prevalence has significantly increased in the observed period and exceeded 475,000 cases in 2011. In addition to demographic aging of the Czech population, the cancer burden has also increased due to the growing incidence of multiple primary tumors (recently more than 15\% of the total incidence). The most frequent diagnoses include colorectal cancer, lung cancer, breast cancer, and prostate cancer. Although some neoplasms are increasingly diagnosed at an early stage (e. g. the proportion of stage I or II was $75.3 \%$ for female breast cancer and $84.2 \%$ for skin melanoma), the numbers of early diagnosed cases are generally insufficient, even in the case of highly prevalent cancers such as colorectal carcinoma (only $46.1 \%$ of incident cases are diagnosed at stage I or II, according to recent data). Conclusion: Population-based data on malignant tumors are available in the Czech Republic. The data survey can help us define national cancer management priorities. The current priority is to achieve a sustained reduction of cases diagnosed at an advanced stage and reduction of the significant regional differences in diagnostic efficiency.
\end{abstract}

\section{Key words}

epidemiology - incidence - mortality - Czech Republic - neoplasms, multiple primary staging - Czech National Cancer Registry
Validation of the Czech National Cancer Registry and population-based monitoring of cancer disparities are supported by grant from the Internal Grant Agency of the Czech Ministry of Health No. NT/13660-4. The authors also greatly acknowledge professional support of data managers of the Czech National Cancer Registry.

The authors declare they have no potential conflicts of interest concerning drugs, products, or services used in the study.

Autoři deklarují, že $v$ souvislosti s předmětem studie nemají žádné komerční zájmy.

The Editorial Board declares that the manuscript met the ICMJE "uniform requirements" for biomedical papers.

Redakční rada potvrzuje, že rukopis práce splnil ICMJE kritéria pro publikace zasílané do biomedicínských časopisů.

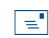

Assoc. Prof. Ladislav Dusek, PhD Institute of Biostatistics and Analyses Faculty of Medicine and Faculty of Science Masaryk University

Kamenice 126/3

62500 Brno

Czech Republic

e-mail:dusek@iba.muni.cz

Submitted/Obdrženo: 8. 10. 2014

Accepted/Přijato: 13. 11. 2014 


\section{Souhrn}

Východiska: ČR patr̂í mezi onkologicky nejzatíženější státy v evropském i celosvětovém měřítku. Cílem této studie je shrnout dlouhodobé trendy v epidemiologii nádorů, včetně nových odhadů incidence a mortality za rok 2011. Data a metody: Národní onkologický registr ČR (NOR) byl založen v roce 1977 a zpřístupňuje informace o epidemiologii nádorů za 34 let při 100\% pokrytí onkologických diagnóz a české populace. Analýza epidemiologie nádorů se dále opírá o demografická data a o data registru zemřelých ČR. Epidemiologická data jsou dostupná on-line na portálu www.svod.cz. Výsledky: Hrubá incidence zhoubných nádorů (včetně nemelanomových nádorů kůže) dosáhla v roce 2011 hodnoty 802 př́padů na 100000 mužů a 681 případů na 100000 žen. Roční hrubá mortalita přesáhla 258 úmrtí na 100000 obyvatel; každoročně umírá z př́činy zhoubného nádoru více než 27000 osob. Celková incidence nádorových onemocnění setrvale roste, růstový index dosáhl za období 2001-2011 hodnoty $+27,6 \%$. Naopak mortalita je ve stejném období stabilizována (růstový index $-5,0 \%$ ). Důsledkem rostoucí incidence a stabilizované mortality je růst prevalence, která v roce 2011 přesáhla 475000 osob. K růstu populační zátěže přispívá kromě demografického stárnutí populace také rostoucí incidence vícečetných primárních nádorů u téhož pacienta ( $v$ recentním období více než 15 \% z celkové incidence). Mezi nejčastější malignity české populace patří nádory kolorekta, prsu u žen, plic a prostaty. Ačkoliv je řada onkologických diagnóz stále častěji odhalována v méně pokročilých stadiích (např. stadium I + II u nádorů prsu: 75,3 \%, u maligního melanomu: 84,2 \%), celkově je včasná diagnostika zhoubných nádorů v ČR nedostatečná. To se týká i velmi častých typů nádorových onemocnění, jako je kolorektální karcinom (pouze 46,1 \% nově diagnostikovaných pacientů je zachyceno ve stadiu I + II). Závěr: ČR je vybavena kvalitním a funkčním zázemím pro sběr a analýzu onkologických populačních dat. Dostupná data napomáhají definovat priority organizace onkologické péče, kterými jsou jednoznačně posílení záchytu časných stadií onkologických onemocnění a redukce existujících rozdílů mezi regiony ČR.

\section{Klíčová slova}

epidemiologie - incidence - mortalita - Česká republika - nádory mnohočetné primární - stadium - Národní onkologický registr

\section{Introduction}

Cancer epidemiology is of ever growing importance due to the high incidence rates of malignant tumors [1,2]. In recent years, several comprehensive worldwide and European studies on cancer incidence and prevalence have been published [1-5]. These reports provide unambiguous data-based evidence of a rapid increase of cancer incidence in most European countries. According to Ferlay et al [1] there were 3.45 million newly diagnosed cancer cases (excluding non-melanoma skin cancer) and 1.75 million deaths from cancer in Europe in 2012. Therefore, cancer is an important public health issue in Europe, with measures aiming to diminish the continuous growth of this burden being only partially effective. The Czech Republic is no exception in this respect; quite the opposite: the Czech population ranks among those with the highest burden worldwide [6].

The current role of cancer epidemiology is not purely descriptive. Knowledge regarding age- or stage-specific trends is necessary to evaluate the effectiveness of diagnostic procedures, identify weak points in the management of cancer care, or analyze associations related to therapeutic outcomes [7]. For obvious reasons, survival occupies a dominant position among all health care end-points of population-based cancer registries. A new edition of the international population-based survival study EUROCARE-5 was published recently [8]. A significant improvement in attained survival rates has been reported for most European countries. In particular, the 5-year relative survival reported for cancer patients in the Czech Republic has improved considerably and is now substantially higher than the survival reported for the entire Eastern European region. These promising results have recently been confirmed in a detailed study on time trends in stage-specific survival in the Czech Republic [9].

Nevertheless, evident regional differences still persist, mostly associated with late diagnosis of advanced disease stage and with more or less specific care disparities. Based on current epidemiologic trends, it seems that promising novel research technologies and the practice of personalized medicine have not yet been effectively and widely translated into cancer control. Epidemiologic data thus represent a strategic contribution to the management of this field [10].

Reliable epidemiologic analyses that would be useful for controlling and planning cancer prevention, diagnostics, and therapy require extensive population-based data covering all the relevant parameters. In particular, records identifying morphology and clinical stage of tumors are of utmost importance. Such clinical registries allow for monitoring of early detection of cancer, which is currently a major area of interest in Europe [11], and is closely related to cancer patients' survival. Population-based cancer registries constitute an indispensable component of the functional information systems of organized screening programs, along with specialized cancer screening registries [12]. It is essential that these data be used in order to provide necessary monitoring and evaluation of cancer screening programs according to European guidelines [13-15]. An organized approach to secondary prevention is needed to maintain a favorable balance between the benefits and dangers of the screening programs that aim to decrease cancer mortality in the future.

However, not all national cancer registries can provide such complex information, and therefore many epidemiologic analyses covering large geographic areas cannot address the health care topics adequately. In addition, international epidemiologic surveys often suffer from partially inconsistent data from participating countries or 
Tab. 1. Demographic and cancer-related characteristics of the Czech population.

\begin{tabular}{|c|c|c|c|}
\hline Parameter & Males & Females & Total \\
\hline population size & $5,158,210$ & $5,347,235$ & $10,505,445$ \\
\hline fertility rate & - & - & 1.427 \\
\hline \multicolumn{4}{|l|}{ age (2011) } \\
\hline mean/median (years) & $39.6 / 38.5$ & $42.5 / 41.5$ & $41.1 / 40.5$ \\
\hline $25-75^{\text {th }}$ percentile (years) & $23.5-56.5$ & $24.5-60.5$ & $24.5-58.5$ \\
\hline$>50$ years (in \%) & $32.4 \%$ & $38.2 \%$ & $35.3 \%$ \\
\hline life expectancy at birth (years) & 74.7 & 80.7 & - \\
\hline annual overall mortality & 54,141 & 52,707 & 106,848 \\
\hline \multicolumn{4}{|l|}{ causes of death (\%) } \\
\hline diseases of the circulatory system (I00-199) & $44.6 \%$ & $54.3 \%$ & $49.3 \%$ \\
\hline neoplasms (C00-D48) & $28.0 \%$ & $23.4 \%$ & $25.8 \%$ \\
\hline $\begin{array}{l}\text { injury, poisoning and certain other consequences } \\
\text { of external causes (S00-T98) }\end{array}$ & $7.7 \%$ & $3.5 \%$ & $5.6 \%$ \\
\hline diseases of the respiratory system (J00-J99) & $6.0 \%$ & $4.6 \%$ & $5.3 \%$ \\
\hline diseases of the digestive system (K00-K93) & $4.7 \%$ & $3.7 \%$ & $4.2 \%$ \\
\hline endocrine, nutritional and metabolic diseases (E00-E90) & $2.2 \%$ & $3.0 \%$ & $2.6 \%$ \\
\hline other causes & $6.8 \%$ & $7.4 \%$ & $7.1 \%$ \\
\hline
\end{tabular}

from temporary interruption, as was the case with the Europe Against Cancer Programme of the European Commission [16]. Separate processing of national databases enabling extraction of clinically relevant information is, therefore, still of great value. That is why this overview of recent cancer epidemiology in the Czech Republic has been prepared. The article presents data on cancer incidence and mortality in the Czech population, drawing on more than 30 years' experience with nationwide cancer data collection. Up-to-date estimates of incidence and mortality rates after 2011 are presented in the context of long-term trends. In addition to a general descriptive approach, detailed stage-specific trends and regional differences are discussed as well.

\section{Data sources and methods \\ Demographic data}

As a standard part of population monitoring, the Czech Statistical Office administrates data on the demographic structure of the Czech population and publishes these data on its website $[17,18]$. This fully consolidated data source describes the main demographic characteristics of the Czech population, such as the total population, the age structure, life expectancy, as well as predictions of demographic parameters up to 2065 . The basic demographic characteristics of the Czech population are summarized in Tab. 1.

\section{Czech National Cancer Registry (CNCR)}

The CNCR was launched in 1976 and instituted as a national database covering $100 \%$ of cancer diagnoses within the entire Czech population. The most recent validated outcomes are from 2011, and the CNCR database contains more than 1.9 million records. The registration of malignant neoplasms is stipulated by the legislation and is obligatory. The CNCR is a part of the National Health Information System (NHIS) and is administered by the Institute of Health Information and Statistics of the Czech Republic [19]. The CNCR is accepted as a key database component of the Czech National
Cancer Control Program, designated to report regular and timely estimates of the cancer burden in the Czech population. For this purpose, automated analytic tools with final outputs were developed. The CNCR is equipped with an information system which, among other things, provides a freely accessible analytical web portal (www.svod.cz) [20].

\section{Incidence data and associated} attributes

The CNCR contains personal data of patients, data describing malignant tumors, and diagnostic details (including morphology classification and stage), data on patients' treatment, as well as data on post-treatment follow-up. The registration of a new case begins with the initial cancer diagnosis, morphological verification and staging. Subsequently, basic records on primary therapy (modalities used), therapeutic strategy, follow-up data and/or deaths are transferred into the registration forms. The forms are directly linked to the database on the basis of the standardized data model and data processing rules [21]. Malignant 
Tab. 2. Causes of death in the Czech Republic in 2011 according to age.

\begin{tabular}{|c|c|c|c|c|c|c|c|}
\hline & $\begin{array}{c}0-14 \text { yrs } \\
n=470\end{array}$ & $\begin{array}{c}15-29 y r s \\
n=967\end{array}$ & $\begin{array}{l}30-49 \text { yrs } \\
n=4,530\end{array}$ & $\begin{array}{l}50-64 \text { yrs } \\
n=18,535\end{array}$ & $\begin{array}{l}65-74 \text { yrs } \\
n=21,781\end{array}$ & $\begin{array}{c}75+\text { yrs } \\
n=60,565\end{array}$ & $\begin{array}{c}\text { Total } \\
n=106,848\end{array}$ \\
\hline neoplasms (C00-D48) & $\begin{array}{c}31 \\
(6.6 \%)\end{array}$ & $\begin{array}{c}97 \\
(10.0 \%)\end{array}$ & $\begin{array}{c}1,148 \\
(25.3 \%)\end{array}$ & $\begin{array}{l}7,275 \\
(39.3 \%)\end{array}$ & $\begin{array}{c}8,185 \\
(37.6 \%)\end{array}$ & $\begin{array}{c}10,803 \\
(17.8 \%)\end{array}$ & $\begin{array}{c}27,539 \\
(25.8 \%)\end{array}$ \\
\hline $\begin{array}{l}\text { diseases of the circulatory system } \\
(100-199)\end{array}$ & $\begin{array}{c}15 \\
(3.2 \%)\end{array}$ & $\begin{array}{c}70 \\
(7.2 \%)\end{array}$ & $\begin{array}{c}850 \\
(18.8 \%)\end{array}$ & $\begin{array}{c}5,788 \\
(31.2 \%)\end{array}$ & $\begin{array}{c}8,927 \\
(41.0 \%)\end{array}$ & $\begin{array}{l}37,075 \\
(61.2 \%)\end{array}$ & $\begin{array}{l}52,725 \\
(49.3 \%)\end{array}$ \\
\hline $\begin{array}{l}\text { injury, poisoning and certain other con- } \\
\text { sequences of external causes (S00-T98) }\end{array}$ & $\begin{array}{c}70 \\
(14.9 \%)\end{array}$ & $\begin{array}{c}617 \\
(63.8 \%)\end{array}$ & $\begin{array}{l}1,330 \\
(29.4 \%)\end{array}$ & $\begin{array}{l}1,518 \\
(8.2 \%)\end{array}$ & $\begin{array}{c}695 \\
(3.2 \%)\end{array}$ & $\begin{array}{l}1,743 \\
(2.9 \%)\end{array}$ & $\begin{array}{l}5,973 \\
(5.6 \%)\end{array}$ \\
\hline $\begin{array}{l}\text { diseases of the respiratory system } \\
\text { (J00-J99) }\end{array}$ & $\begin{array}{c}18 \\
(3.8 \%)\end{array}$ & $\begin{array}{c}35 \\
(3.6 \%)\end{array}$ & $\begin{array}{c}156 \\
(3.4 \%)\end{array}$ & $\begin{array}{c}939 \\
(5.1 \%)\end{array}$ & $\begin{array}{l}1,141 \\
(5.2 \%)\end{array}$ & $\begin{array}{l}3,401 \\
(5.6 \%)\end{array}$ & $\begin{array}{l}5,690 \\
(5.3 \%)\end{array}$ \\
\hline $\begin{array}{l}\text { diseases of the digestive system } \\
\text { (K00-K93) }\end{array}$ & $\begin{array}{c}8 \\
(1.7 \%)\end{array}$ & $\begin{array}{c}19 \\
(2.0 \%)\end{array}$ & $\begin{array}{c}485 \\
(10.7 \%)\end{array}$ & $\begin{array}{l}1,459 \\
(7.9 \%)\end{array}$ & $\begin{array}{c}910 \\
(4.2 \%)\end{array}$ & $\begin{array}{l}1,650 \\
(2.7 \%)\end{array}$ & $\begin{array}{l}4,531 \\
(4.2 \%)\end{array}$ \\
\hline $\begin{array}{l}\text { endocrine, nutritional and metabolic } \\
\text { diseases (E00-E90) }\end{array}$ & $\begin{array}{c}10 \\
(2.1 \%)\end{array}$ & $\begin{array}{c}17 \\
(1.8 \%)\end{array}$ & $\begin{array}{c}79 \\
(1.7 \%)\end{array}$ & $\begin{array}{c}353 \\
(1.9 \%)\end{array}$ & $\begin{array}{c}651 \\
(3.0 \%)\end{array}$ & $\begin{array}{l}1,684 \\
(2.8 \%)\end{array}$ & $\begin{array}{l}2,794 \\
(2.6 \%)\end{array}$ \\
\hline $\begin{array}{l}\text { diseases of the nervous system } \\
\text { (G00-G99) }\end{array}$ & $\begin{array}{c}34 \\
(7.2 \%)\end{array}$ & $\begin{array}{c}59 \\
(6.1 \%)\end{array}$ & $\begin{array}{c}136 \\
(3.0 \%)\end{array}$ & $\begin{array}{c}280 \\
(1.5 \%)\end{array}$ & $\begin{array}{c}399 \\
(1.8 \%)\end{array}$ & $\begin{array}{l}1,224 \\
(2.0 \%)\end{array}$ & $\begin{array}{l}2,132 \\
(2.0 \%)\end{array}$ \\
\hline $\begin{array}{l}\text { diseases of the genitourinary system } \\
\text { (N00-N99) }\end{array}$ & $\begin{array}{c}2 \\
(0.4 \%)\end{array}$ & $\begin{array}{c}1 \\
(0.1 \%)\end{array}$ & $\begin{array}{c}22 \\
(0.5 \%)\end{array}$ & $\begin{array}{c}139 \\
(0.7 \%)\end{array}$ & $\begin{array}{c}206 \\
(0.9 \%)\end{array}$ & $\begin{array}{c}846 \\
(1.4 \%)\end{array}$ & $\begin{array}{l}1,216 \\
(1.1 \%)\end{array}$ \\
\hline other diseases, disorders and conditions & $\begin{array}{c}282 \\
(60.0 \%)\end{array}$ & $\begin{array}{c}52 \\
(5.4 \%)\end{array}$ & $\begin{array}{c}324 \\
(7.2 \%)\end{array}$ & $\begin{array}{c}784 \\
(4.2 \%)\end{array}$ & $\begin{array}{c}667 \\
(3.1 \%)\end{array}$ & $\begin{array}{c}2,139 \\
(3.5 \%)\end{array}$ & $\begin{array}{c}4,248 \\
(4.0 \%)\end{array}$ \\
\hline
\end{tabular}

neoplasms are recorded according to the International statistical classification of diseases and related health problems, currently the 10th revision (ICD-10) [22], and International Classification of Diseases for Oncology (ICD-O, currently $3^{\text {rd }}$ revision) [23].

Tumors are staged on the basis of TNM classification systems, currently $7^{\text {th }}$ edition [24]. For the purposes of this article, all cases recorded in the CNCR, including DCO (death certificate only) records, were calculated as incident cases. Identification of multiple cancers in the same person was accurately controlled in the CNCR database, based on strict recognition of the patient's individual code, the diagnosis date and diagnostic typology of multiple cancers.

\section{Mortality data}

The Czech legislation requires that all deaths in the Czech Republic be registered in the Death Records Database, a civil registration system [18]. For this purpose, standardized Death Certificates (internationally recommended by WHO [25]) are designed to collect precise data on the cause of death in each individual, and are typically written up and verified by a general practitioner. The causes of death are classified according to ICD-10, which provides standardized nomenclature in this field [22]. This system ensures comparability of official Czech mortality data with common international reporting. The coding of the underlying cause of death can be controlled against an independently and promptly completed CNCR. The CNCR serves as another source of mortality data in the Czech Republic. Here, the individual records on the cause of death according to the Death Certificate are directly linked to diagnostic records on decedents in the cancer registry, which can be used to code cause-specific mortality with respect to different cancer diagnoses. The death of a given person from a malignant tumor is indexed with respect to the main cancer diagnosis together with the immediate or the primary cause of death. The system therefore allows the data managers to code distinct cancer entities, and the records on causes of death are finally kept separately in two information systems. The system makes it possible to check the correctness of CNCR data retrospectively and to verify the validity of mortality data on cancer patients according to the internationally accepted rules $[26,27]$.

\section{Data analysis}

Basic epidemiologic measures such as the crude incidence and mortality rates, age-standardized rates and lifetime cumulative cancer rates were calculated according to the standardized statistical methodology $[28,29]$. Cumulative risk is expressed as the probability that an individual will develop the given cancer type during the age span $0-74$ years, in the absence of other competing causes of death. Annual incidence and mortality rates per 100,000 individuals (crude incidence) were calculated by gender and related to the Czech population structure in 2011. Age-standardized rates adjusted for the World and European population were calculated using age standards according to Waterhouse et al [30].

\section{Results}

The Czech Republic is one of the countries with the highest cancer 
Tab. 3. Cancer epidemiology in the Czech Republic (all cancers including skin neoplasms C00-C97, data from 2011).

\begin{tabular}{|c|c|c|c|}
\hline Parameter & Males & Females & Total \\
\hline \multicolumn{4}{|l|}{ overall incidence } \\
\hline absolute number & 41,349 & 36,424 & 77,773 \\
\hline rate per 100,000 & 801.6 & 681.2 & 740.3 \\
\hline incidence - ranking of Czech Republic worldwide (ASR(W), estimate from 2012) & $10^{\text {th }}$ & $16^{\text {th }}$ & $14^{\text {th }}$ \\
\hline lifetime cumulative risk of cancer (age $0-74$ years) ${ }^{1}$ & 34.2 & 25.3 & 29.3 \\
\hline \multicolumn{4}{|l|}{ overall mortality ${ }^{2}$} \\
\hline absolute number & 15,008 & 12,163 & 27,171 \\
\hline cases per 100,000 population & 291.0 & 227.5 & 258.6 \\
\hline mortality - ranking of Czech Republic worldwide (ASR(W), estimate from 2012)1 & $24^{\text {th }}$ & $46^{\text {th }}$ & $30^{\text {th }}$ \\
\hline mortality/incidence ratio ${ }^{2}$ & 0.36 & 0.33 & 0.35 \\
\hline \multicolumn{4}{|l|}{ prevalence } \\
\hline absolute number & 206,969 & 268,493 & 475,462 \\
\hline cases per 100,000 population & 4,012 & 5,021 & 4,526 \\
\hline \multicolumn{4}{|l|}{ growth index (2001-2011) } \\
\hline incidence & $32.0 \%$ & $22.8 \%$ & $27.6 \%$ \\
\hline mortality $^{2}$ & $-4.7 \%$ & $-5.6 \%$ & $-5.0 \%$ \\
\hline prevalence & $62.4 \%$ & $50.0 \%$ & $55.0 \%$ \\
\hline
\end{tabular}

${ }^{1}$ All cancers excluding non-melanoma skin cancer (C00-C97) in age 0-74. Adapted from Ferlay et al [2].

${ }^{2}$ Mortality statistics - Czech Statistical Office

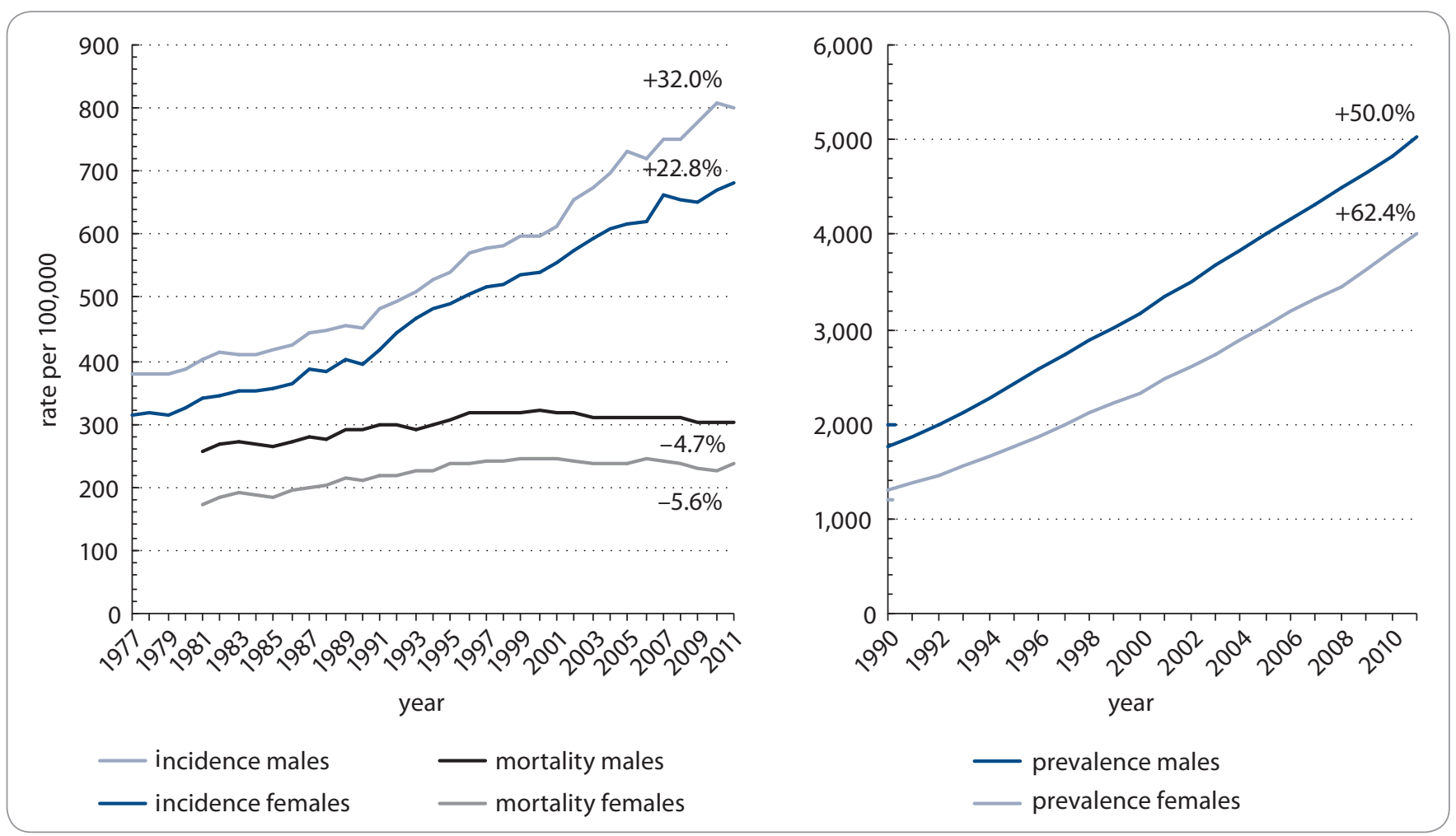

Fig. 1. Overall incidence, mortality and prevalence of all cancer diagnoses (C00-C97) in time trend (Czech National Cancer Registry, 1977-2011). \% - growth index (2001-2011) 
Tab. 4. Trends in incidence rates of malignant tumors excluding non-melanoma skin cancer (C00-C97 excluding C44) in the Czech Republic.

\begin{tabular}{|c|c|c|c|c|c|c|}
\hline & \multicolumn{2}{|c|}{ Males } & \multicolumn{2}{|c|}{ Females } & \multicolumn{2}{|c|}{ Whole population } \\
\hline & $\begin{array}{c}\text { number } \\
\text { of neoplasms }\end{array}$ & $\begin{array}{c}\text { rate per } \\
100,000 \text { males }\end{array}$ & $\begin{array}{c}\text { number } \\
\text { of neoplasms }\end{array}$ & $\begin{array}{c}\text { rate per } \\
100,000 \text { females }\end{array}$ & $\begin{array}{c}\text { number } \\
\text { of neoplasms }\end{array}$ & $\begin{array}{c}\text { rate per } \\
100,000 \text { persons }\end{array}$ \\
\hline 1980 & 16,750 & 333.9 & 14,538 & 273.3 & 31,288 & 302.7 \\
\hline 1990 & 19,309 & 383.4 & 17,653 & 331.4 & 36,962 & 356.6 \\
\hline 2000 & 23,762 & 475.3 & 22,545 & 427.5 & 46,307 & 450.8 \\
\hline 2005 & 27,856 & 556.8 & 24,368 & 464.3 & 52,224 & 509.4 \\
\hline 2011 & 30,621 & 593.6 & 26,473 & 495.1 & 57,094 & 543.5 \\
\hline $\begin{array}{l}\text { growth index: } \\
\text { 1980-1990 }\end{array}$ & & $17.0 \%$ & & $23.1 \%$ & & $19.8 \%$ \\
\hline $\begin{array}{l}\text { growth index: } \\
\text { 1990-2000 }\end{array}$ & & $23.9 \%$ & & $28.7 \%$ & & $26.2 \%$ \\
\hline $\begin{array}{l}\text { growth index: } \\
\text { 2000-2011 }\end{array}$ & & $24.9 \%$ & & $14.9 \%$ & & $20.1 \%$ \\
\hline
\end{tabular}

burden, and mortality from cancer contributes $25.8 \%$ to the overall population mortality (Tab. 1). The highest relative proportion of cancer mortality in relation to other competing causes of death was observed in the age group 50-64 years (39.3\%, Tab. 2). The male population ranks $10^{\text {th }}$ worldwide in respect of cancer incidence and $24^{\text {th }}$ in respect of cancer mortality. The female population ranks $16^{\text {th }}$ in respect of the worldwide incidence statistics and $46^{\text {th }}$ in respect of mortality (Tab. 3). In 2011, 77,773 newly diagnosed cases
(740.3 per 100,000 individuals) of all cancers including skin neoplasms (C00-C97) were diagnosed. In total, 27,171 cancer deaths were registered in 2011 (258.6 per 100,000 individuals) (Tab. 3). The crude incidence rate has continuously increased with the growth index $+27.6 \%$ in the last decade (2001-2011), while the crude mortality rate stabilized in late $1990 \mathrm{~s}$ and recently even started to decrease with the growth index $-5.0 \%$ over the time period 2001-2011 (Fig. 1, Tab. 3, 4). Growing incidence and stabilized mortality necessarily result in increased prevalence, which exceeded 475,000 of cases in 2011 (Tab. 3).

The age-standardized incidence and mortality rates (World and European age standard) as well as crude incidence and mortality rates for all main cancer diagnostic groups according to gender are presented in Tab. 5 and 6. The cancer types most common in the male population (absolute number in 2011) include prostate cancer $(6,965)$, followed by colorectal cancer $(4,755)$ and lung cancer $(4,482)$. In women, breast

Tab. 5. Incidence and mortality of malignant neoplasms in the Czech Republic according to diagnosis - male population in 2011.

\begin{tabular}{|c|c|c|c|c|c|c|}
\hline \multirow[t]{2}{*}{ Diagnosis } & & \multicolumn{2}{|c|}{ Number of cases } & \multicolumn{2}{|c|}{ Age-standardized rate } & \multirow{2}{*}{$\begin{array}{l}\text { Lifetime } \\
\text { cumulative risk } \\
\text { (0-74 years) }\end{array}$} \\
\hline & & absolute & $\begin{array}{c}\text { per } \\
100,000 \text { males }\end{array}$ & $\operatorname{ASR}(W)$ & ASR(E) & \\
\hline \multirow{3}{*}{$\begin{array}{l}\text { oral cavity } \\
\text { and pharynx } \\
(\mathrm{COO}-\mathrm{C} 14)\end{array}$} & incidence & 1,059 & 20.5 & 12.7 & 17.7 & 1.44 \\
\hline & mortality & 556 & 10.8 & 6.6 & 9.2 & \\
\hline & prevalence & 5,227 & 101.3 & & & \\
\hline \multirow{3}{*}{$\begin{array}{l}\text { oesophagus } \\
\text { (C15) }\end{array}$} & incidence & 440 & 8.5 & 5.0 & 7.1 & 0.69 \\
\hline & mortality & 388 & 7.5 & 4.3 & 6.3 & \\
\hline & prevalence & 760 & 14.7 & & & \\
\hline \multirow{3}{*}{$\begin{array}{l}\text { stomach } \\
\text { (C16) }\end{array}$} & incidence & 900 & 17.4 & 9.6 & 14.6 & 1.21 \\
\hline & mortality & 632 & 12.3 & 6.7 & 10.3 & \\
\hline & prevalence & 2,790 & 54.1 & & & \\
\hline
\end{tabular}


Tab. 5 - continue. Incidence and mortality of malignant neoplasms in the Czech Republic according to diagnosis - male population in 2011.

\begin{tabular}{|c|c|c|c|c|c|c|}
\hline \multirow[t]{2}{*}{ Diagnosis } & & \multicolumn{2}{|c|}{ Number of cases } & \multicolumn{2}{|c|}{ Age-standardized rate } & \multirow{2}{*}{$\begin{array}{l}\text { Lifetime } \\
\text { cumulative risk } \\
\text { (0-74 years) }\end{array}$} \\
\hline & & absolute & $\begin{array}{c}\text { per } \\
100,000 \text { males }\end{array}$ & $\operatorname{ASR}(W)$ & ASR(E) & \\
\hline \multirow{3}{*}{$\begin{array}{l}\text { colorectal cancer } \\
\text { (C18-C21) }\end{array}$} & incidence & 4,755 & 92.2 & 51.2 & 76.6 & 6.26 \\
\hline & mortality & 2,122 & 41.1 & 21.7 & 34.2 & \\
\hline & prevalence & 28,786 & 558.1 & & & \\
\hline \multirow[t]{3}{*}{ liver (C22) } & incidence & 590 & 11.4 & 6.5 & 9.6 & 0.84 \\
\hline & mortality & 490 & 9.5 & 5.2 & 7.9 & \\
\hline & prevalence & 521 & 10.1 & & & \\
\hline \multirow{3}{*}{$\begin{array}{l}\text { gallbladder } \\
\text { and billiary tract } \\
\text { (C23-C24) }\end{array}$} & incidence & 351 & 6.8 & 3.6 & 5.7 & 0.42 \\
\hline & mortality & 279 & 5.4 & 2.8 & 4.5 & \\
\hline & prevalence & 549 & 10.6 & & & \\
\hline \multirow[t]{3}{*}{ pancreas (C25) } & incidence & 1,111 & 21.5 & 12.1 & 18.0 & 1.42 \\
\hline & mortality & 1,037 & 20.1 & 11.1 & 16.9 & \\
\hline & prevalence & 973 & 18.9 & & & \\
\hline \multirow[t]{3}{*}{ larynx (C32) } & incidence & 456 & 8.8 & 5.3 & 7.5 & 0.71 \\
\hline & mortality & 238 & 4.6 & 2.7 & 3.9 & \\
\hline & prevalence & 3,548 & 68.8 & & & \\
\hline \multirow{3}{*}{$\begin{array}{l}\text { trachea, bron- } \\
\text { chus and lung } \\
\text { (C33-C34) }\end{array}$} & incidence & 4,482 & 86.9 & 48.2 & 71.6 & 6.62 \\
\hline & mortality & 3,911 & 75.8 & 41.6 & 62.2 & \\
\hline & prevalence & 7,474 & 144.9 & & & \\
\hline \multirow{3}{*}{$\begin{array}{l}\text { melanoma of skin } \\
\text { (C43) }\end{array}$} & incidence & 1,086 & 21.1 & 12.6 & 18.0 & 1.34 \\
\hline & mortality & 201 & 3.9 & 2.2 & 3.3 & \\
\hline & prevalence & 9,743 & 188.9 & & & \\
\hline \multirow{3}{*}{$\begin{array}{l}\text { non-melanoma } \\
\text { skin (C44) }\end{array}$} & incidence & 10,728 & 208.0 & 109.8 & 174.3 & 7.45 \\
\hline & mortality & 84 & 1.6 & 0.8 & 1.4 & \\
\hline & prevalence & 68,385 & 1,326 & & & \\
\hline \multirow{3}{*}{$\begin{array}{l}\text { soft tissue } \\
\text { (C47, C49) }\end{array}$} & incidence & 160 & 3.1 & 2.2 & 2.8 & 0.19 \\
\hline & mortality & 57 & 1.1 & 0.8 & 1.0 & \\
\hline & prevalence & 1,376 & 26.7 & & & \\
\hline \multirow[t]{3}{*}{ prostate (C61) } & incidence & 6,965 & 135.0 & 74.0 & 110.6 & 8.67 \\
\hline & mortality & 1,314 & 25.5 & 12.7 & 21.7 & \\
\hline & prevalence & 39,866 & 772.9 & & & \\
\hline \multirow[t]{3}{*}{ testis (C62) } & incidence & 467 & 9.1 & 7.6 & 8.3 & 0.60 \\
\hline & mortality & 38 & 0.7 & 0.6 & 0.7 & \\
\hline & prevalence & 8,617 & 167.1 & & & \\
\hline \multirow[t]{3}{*}{ kidney (C64) } & incidence & 1,940 & 37.6 & 22.3 & 31.9 & 2.59 \\
\hline & mortality & 647 & 12.5 & 6.8 & 10.5 & \\
\hline & prevalence & 12,621 & 244.7 & & & \\
\hline \multirow[t]{3}{*}{ bladder (C67) } & incidence & 1,608 & 31.2 & 16.8 & 25.9 & 2.11 \\
\hline & mortality & 507 & 9.8 & 5.1 & 8.2 & \\
\hline & prevalence & 12,689 & 246.0 & & & \\
\hline
\end{tabular}


Tab. 5 - continue. Incidence and mortality of malignant neoplasms in the Czech Republic according to diagnosis - male population in 2011.

\begin{tabular}{|c|c|c|c|c|c|c|}
\hline \multicolumn{2}{|l|}{ Diagnosis } & \multicolumn{2}{|c|}{ Number of cases } & \multicolumn{2}{|c|}{ Age-standardized rate } & \multirow{2}{*}{$\begin{array}{l}\text { Lifetime } \\
\text { cumulative risk } \\
\text { (0-74 years) }\end{array}$} \\
\hline & & absolute & $\begin{array}{c}\text { per } \\
100,000 \text { males }\end{array}$ & $\operatorname{ASR}(W)$ & ASR(E) & \\
\hline \multirow{3}{*}{$\begin{array}{l}\text { brain, nervous } \\
\text { system (C70-72) }\end{array}$} & incidence & 439 & 8.5 & 6.2 & 7.6 & 0.65 \\
\hline & mortality & 389 & 7.5 & 5.0 & 6.6 & \\
\hline & prevalence & 1,705 & 33.1 & & & \\
\hline \multirow[t]{3}{*}{ thyroid (C73) } & incidence & 215 & 4.2 & 2.8 & 3.7 & 0.30 \\
\hline & mortality & 36 & 0.7 & 0.4 & 0.6 & \\
\hline & prevalence & 1,994 & 38.7 & & & \\
\hline \multirow{3}{*}{$\begin{array}{l}\text { Hodgkin lym- } \\
\text { phoma (C81) }\end{array}$} & incidence & 152 & 2.9 & 2.5 & 2.7 & 0.20 \\
\hline & mortality & 30 & 0.6 & 0.3 & 0.5 & \\
\hline & prevalence & 2,620 & 50.8 & & & \\
\hline \multirow{3}{*}{$\begin{array}{l}\text { non-Hodgkin } \\
\text { lymphoma } \\
(\mathrm{C} 82-\mathrm{C} 85, \mathrm{C} 96)\end{array}$} & incidence & 723 & 14.0 & 8.7 & 12.1 & 0.90 \\
\hline & mortality & 317 & 6.1 & 3.3 & 5.2 & \\
\hline & prevalence & 4,877 & 94.5 & & & \\
\hline \multirow{3}{*}{$\begin{array}{l}\text { multiple } \\
\text { myeloma (C90) }\end{array}$} & incidence & 245 & 4.7 & 2.7 & 3.9 & 0.34 \\
\hline & mortality & 161 & 3.1 & 1.7 & 2.6 & \\
\hline & prevalence & 982 & 19.0 & & & \\
\hline \multirow{3}{*}{$\begin{array}{l}\text { leukaemia } \\
\text { (C91-C95) }\end{array}$} & incidence & 721 & 14.0 & 8.8 & 12.1 & 0.98 \\
\hline & mortality & 461 & 8.9 & 4.9 & 7.5 & \\
\hline & prevalence & 4,056 & 78.6 & & & \\
\hline \multirow{3}{*}{$\begin{array}{l}\text { all malignant but } \\
\text { skin (C00-C } 97 \\
\text { but C44) }\end{array}$} & incidence & 30,621 & 593.6 & 341.3 & 496.8 & 31.28 \\
\hline & mortality & 14,924 & 289.3 & 158.5 & 242.0 & \\
\hline & prevalence & 148,717 & $2,883.1$ & & & \\
\hline \multirow[t]{3}{*}{ all malignant } & incidence & 41,349 & 801.6 & 451.1 & 671.0 & 34.96 \\
\hline & mortality & 15,008 & 291.0 & 159.3 & 243.4 & \\
\hline & prevalence & 206,969 & $4,012.4$ & & & \\
\hline
\end{tabular}

Mortality statistics: Czech Statistical Office. Lifetime cumulative risk (0-74 years) estimated from period 2007-2011.

cancer is most frequently diagnosed (malignant tumor) $(6,620$ incident cases in 2011), followed by colorectal cancer $(3,421)$, lung cancer $(2,033)$, and uterine cancer $(1,990)$. The highest lifetime cumulative risk (0-74 years) was observed for prostate cancer (men: 8.67), breast cancer (women: 7.19), lung cancer (men: 6.62), and colorectal cancer (men: 6.26).

In addition to demographic aging of the Czech population, the cancer burden has also increased as a consequence of the growing incidence of multiple primary tumors. The data in Tab. 7 document a significantly growing contribution of patients with multiple primary malignancies (both synchronous and metachronous) to the overall incidence. In most prevalent cancers, the rate of multiple malignancies in the same patient represents over $15 \%$ of the overall incidence (2008-2011).

The CNCR database offers accurate stratification of newly diagnosed cases according to clinical stage (Fig. 2). It is evident that early detection of the disease is low, particularly for liver, lung, and pancreatic cancer (Tab. 8). A relatively low proportion of early detected cases can also be observed in highly prevalent neoplasms, such as colorectal cancer (stage I or II: $46.1 \%$ ). Furthermore, in all the above-mentioned diagnoses there is no sign that this situation has improved at all over the 1998-2011 period (Fig. 2). On the other hand, the present survey also revealed several highly prevalent cancers with a continuous increase of early diagnosed cases, including female breast cancer, testicular, prostate, and bladder cancer. For all these diagnoses, the proportion of patients diagnosed in stage I or II has recently exceeded $65 \%$ of incident cases (Tab. 8, Fig. 2). 
Tab. 6. Incidence and mortality of malignant neoplasms in the Czech Republic according to diagnosis - female population in 2011.

\begin{tabular}{|c|c|c|c|c|c|c|}
\hline \multicolumn{2}{|l|}{ Diagnosis } & \multicolumn{2}{|c|}{ Number of cases } & \multicolumn{2}{|c|}{ Age-standardized rate } & \multirow{2}{*}{$\begin{array}{l}\text { Lifetime } \\
\text { cumulative risk } \\
\text { (0-74 years) }\end{array}$} \\
\hline & & absolute & $\begin{array}{c}\text { per } \\
100,000 \text { females }\end{array}$ & $\operatorname{ASR}(W)$ & ASR(E) & \\
\hline \multirow{3}{*}{$\begin{array}{l}\text { oral cavity } \\
\text { and pharynx } \\
(\mathrm{COO}-\mathrm{C} 14)\end{array}$} & incidence & 408 & 7.6 & 4.0 & 5.6 & 0.43 \\
\hline & mortality & 142 & 2.7 & 1.4 & 1.9 & \\
\hline & prevalence & 2,645 & 49.5 & & & \\
\hline \multirow{3}{*}{$\begin{array}{l}\text { oesophagus } \\
\text { (C15) }\end{array}$} & incidence & 91 & 1.7 & 0.8 & 1.1 & 0.11 \\
\hline & mortality & 85 & 1.6 & 0.8 & 1.1 & \\
\hline & prevalence & 161 & 3.0 & & & \\
\hline \multirow[t]{3}{*}{ stomach (C16) } & incidence & 648 & 12.1 & 5.2 & 7.8 & 0.61 \\
\hline & mortality & 460 & 8.6 & 3.5 & 5.3 & \\
\hline & prevalence & 2,321 & 43.4 & & & \\
\hline \multirow{3}{*}{$\begin{array}{l}\text { colorectal cancer } \\
\text { (C18-C21) }\end{array}$} & incidence & 3,421 & 64.0 & 28.3 & 41.8 & 3.19 \\
\hline & mortality & 1,565 & 29.3 & 11.1 & 17.3 & \\
\hline & prevalence & 23,047 & 431.0 & & & \\
\hline \multirow[t]{3}{*}{ liver (C22) } & incidence & 326 & 6.1 & 2.4 & 3.6 & 0.28 \\
\hline & mortality & 276 & 5.2 & 2.0 & 3.1 & \\
\hline & prevalence & 297 & 5.6 & & & \\
\hline \multirow{3}{*}{$\begin{array}{l}\text { gallbladder } \\
\text { and billiary tract } \\
\text { (C23-C24) }\end{array}$} & incidence & 550 & 10.3 & 3.9 & 6.2 & 0.52 \\
\hline & mortality & 477 & 8.9 & 3.5 & 5.5 & \\
\hline & prevalence & 990 & 18.5 & & & \\
\hline \multirow[t]{3}{*}{ pancreas (C25) } & incidence & 1,073 & 20.1 & 8.2 & 12.5 & 0.93 \\
\hline & mortality & 996 & 18.6 & 7.5 & 11.5 & \\
\hline & prevalence & 937 & 17.5 & & & \\
\hline \multirow[t]{3}{*}{ larynx (C32) } & incidence & 70 & 1.3 & 0.7 & 0.9 & 0.08 \\
\hline & mortality & 26 & 0.5 & 0.2 & 0.3 & \\
\hline & prevalence & 516 & 9.6 & & & \\
\hline \multirow{3}{*}{$\begin{array}{l}\text { trachea, bron- } \\
\text { chus and lung } \\
\text { (C33-C34) }\end{array}$} & incidence & 2,033 & 38.0 & 17.6 & 25.6 & 2.15 \\
\hline & mortality & 1,679 & 31.4 & 14.0 & 20.6 & \\
\hline & prevalence & 3,684 & 68.9 & & & \\
\hline \multirow{3}{*}{$\begin{array}{l}\text { melanoma of skin } \\
\text { (C43) }\end{array}$} & incidence & 958 & 17.9 & 10.3 & 13.8 & 1.10 \\
\hline & mortality & 164 & 3.1 & 1.3 & 2.0 & \\
\hline & prevalence & 12,146 & 227.1 & & & \\
\hline \multirow{3}{*}{$\begin{array}{l}\text { non-melanoma } \\
\text { skin (C44) }\end{array}$} & incidence & 9,951 & 186.1 & 79.0 & 118.3 & 6.17 \\
\hline & mortality & 45 & 0.8 & 0.3 & 0.5 & \\
\hline & prevalence & 79,382 & $1,484.5$ & & & \\
\hline \multirow{3}{*}{$\begin{array}{l}\text { soft tissue } \\
(C 47, C 49)\end{array}$} & incidence & 133 & 2.5 & 1.9 & 2.1 & 0.15 \\
\hline & mortality & 50 & 0.9 & 0.5 & 0.7 & \\
\hline & prevalence & 1,331 & 24.9 & & & \\
\hline \multirow{3}{*}{$\begin{array}{l}\text { female breast } \\
\text { (C50) }\end{array}$} & incidence & 6,620 & 123.8 & 67.4 & 92.9 & 7.19 \\
\hline & mortality & 1,725 & 32.3 & 13.9 & 20.8 & \\
\hline & prevalence & 67,261 & 1,257.9 & & & \\
\hline
\end{tabular}


Tab. 6 - continue. Incidence and mortality of malignant neoplasms in the Czech Republic according to diagnosis - female population in 2011.

\begin{tabular}{|c|c|c|c|c|c|c|}
\hline \multicolumn{2}{|l|}{ Diagnosis } & \multicolumn{2}{|c|}{ Number of cases } & \multicolumn{2}{|c|}{ Age-standardized rate } & \multirow{2}{*}{$\begin{array}{c}\text { Lifetime } \\
\text { cumulative risk } \\
\text { (0-74 years) }\end{array}$} \\
\hline & & absolute & $\begin{array}{c}\text { per } \\
100,000 \text { females }\end{array}$ & $\operatorname{ASR}(W)$ & ASR(E) & \\
\hline \multirow{3}{*}{$\begin{array}{l}\text { uterine cervix } \\
\text { (C53) }\end{array}$} & incidence & 1,023 & 19.1 & 13.0 & 16.3 & 1.29 \\
\hline & mortality & 315 & 5.9 & 3.2 & 4.4 & \\
\hline & prevalence & 17,398 & 325.4 & & & \\
\hline \multirow{3}{*}{$\begin{array}{l}\text { uterus } \\
\text { (C54-C55) }\end{array}$} & incidence & 1,990 & 37.2 & 18.7 & 26.7 & 2.27 \\
\hline & mortality & 432 & 8.1 & 3.3 & 5.0 & \\
\hline & prevalence & 24,576 & 459.6 & & & \\
\hline \multirow[t]{3}{*}{ ovary (C56) } & incidence & 1,080 & 20.2 & 11.0 & 15.2 & 1.31 \\
\hline & mortality & 678 & 12.7 & 5.9 & 8.5 & \\
\hline & prevalence & 8,917 & 166.8 & & & \\
\hline \multirow[t]{3}{*}{ kidney (C64) } & incidence & 1,065 & 19.9 & 9.4 & 13.5 & 1.16 \\
\hline & mortality & 398 & 7.4 & 2.8 & 4.4 & \\
\hline & prevalence & 8,307 & 155.4 & & & \\
\hline \multirow[t]{3}{*}{ bladder (C67) } & incidence & 543 & 10.2 & 4.4 & 6.6 & 0.59 \\
\hline & mortality & 192 & 3.6 & 1.2 & 2.0 & \\
\hline & prevalence & 4,921 & 92.0 & & & \\
\hline \multirow{3}{*}{$\begin{array}{l}\text { brain, nervous } \\
\text { system (C70-72) }\end{array}$} & incidence & 418 & 7.8 & 5.1 & 6.2 & 0.49 \\
\hline & mortality & 352 & 6.6 & 3.6 & 4.8 & \\
\hline & prevalence & 1,553 & 29.0 & & & \\
\hline \multirow[t]{3}{*}{ thyroid (C73) } & incidence & 791 & 14.8 & 10.4 & 12.8 & 1.00 \\
\hline & mortality & 40 & 0.7 & 0.2 & 0.4 & \\
\hline & prevalence & 9,127 & 170.7 & & & \\
\hline \multirow{3}{*}{$\begin{array}{l}\text { Hodgkin lym- } \\
\text { phoma (C81) }\end{array}$} & incidence & 132 & 2.5 & 2.3 & 2.3 & 0.15 \\
\hline & mortality & 17 & 0.3 & 0.2 & 0.2 & \\
\hline & prevalence & 2,565 & 48.0 & & & \\
\hline \multirow{3}{*}{$\begin{array}{l}\text { non-Hodgkin } \\
\text { lymphoma } \\
(\mathrm{C} 82-\mathrm{C} 85, \mathrm{C} 96)\end{array}$} & incidence & 700 & 13.1 & 6.6 & 9.2 & 0.72 \\
\hline & mortality & 276 & 5.2 & 2.0 & 3.0 & \\
\hline & prevalence & 4,897 & 91.6 & & & \\
\hline \multirow{3}{*}{$\begin{array}{l}\text { multiple } \\
\text { myeloma (C90) }\end{array}$} & incidence & 238 & 4.5 & 2.0 & 2.9 & 0.25 \\
\hline & mortality & 190 & 3.6 & 1.3 & 2.1 & \\
\hline & prevalence & 977 & 18.3 & & & \\
\hline \multirow{3}{*}{$\begin{array}{l}\text { leukaemia } \\
\text { (C91-C95) }\end{array}$} & incidence & 568 & 10.6 & 5.3 & 7.2 & 0.58 \\
\hline & mortality & 392 & 7.3 & 3.0 & 4.5 & \\
\hline & prevalence & 3,267 & 61.1 & & & \\
\hline \multirow{3}{*}{$\begin{array}{l}\text { all malignant } \\
\text { but skin } \\
\text { (C00-C } 97 \text { but } C 44)\end{array}$} & incidence & 26,473 & 495.1 & 252.3 & 352.6 & 22.73 \\
\hline & mortality & 12,118 & 226.6 & 95.0 & 142.8 & \\
\hline & prevalence & 198,763 & $3,717.1$ & & & \\
\hline \multirow[t]{3}{*}{ all malignant } & incidence & 36,424 & 681.2 & 331.3 & 470.9 & 26.61 \\
\hline & mortality & 12,163 & 227.5 & 95.3 & 143.3 & \\
\hline & prevalence & 268,493 & $5,021.2$ & & & \\
\hline
\end{tabular}

Mortality statistics: Czech Statistical Office. Lifetime cumulative risk (0-74 years) estimated from the period 2007-2011. 
Tab. 7. Trend in incidence of multiple primary cancers diagnosed in period 1977-2011 (documented on records of selected most frequent cancer diagnoses).

\begin{tabular}{|c|c|c|c|c|c|}
\hline \multirow[t]{2}{*}{ Diagnosis } & $\begin{array}{l}\text { Given type of cancer diagnosed as pri- } \\
\text { mary tumor and as subsequent multi- } \\
\text { ple tumor in a patient }\end{array}$ & $\begin{array}{c}\text { Period } \\
1977-1987\end{array}$ & $\begin{array}{c}\text { Period } \\
1988-1997\end{array}$ & $\begin{array}{l}\text { Period } \\
1998-2007\end{array}$ & $\begin{array}{c}\text { Period } \\
2008-2011\end{array}$ \\
\hline & & \multicolumn{4}{|c|}{ annual absolute number ( $\%$ new cases) } \\
\hline \multirow{2}{*}{$\begin{array}{l}\text { colon and re- } \\
\text { ctum (C18-C20) }\end{array}$} & primary tumors & $4,236(95.5 \%)$ & $5,694(91.5 \%)$ & $6,706(86.4 \%)$ & $6,714(82.4 \%)$ \\
\hline & $\begin{array}{l}\text { subsequent multiple tumors developed } \\
\text { in already diagnosed cancer patients }\end{array}$ & 199 (4.5\%) & $527(8.5 \%)$ & $1,056(13.6 \%)$ & $1,433(17.6 \%)$ \\
\hline \multirow[t]{2}{*}{ pancreas (C25) } & primary tumors & $1,094(96.2 \%)$ & $1,351(92.7 \%)$ & $1,501(87.3 \%)$ & $1,711(83.2 \%)$ \\
\hline & $\begin{array}{l}\text { subsequent multiple tumors developed } \\
\text { in already diagnosed cancer patients }\end{array}$ & $43(3.8 \%)$ & $107(7.3 \%)$ & $218(12.7 \%)$ & $346(16.8 \%)$ \\
\hline \multirow[t]{2}{*}{ lung (C34) } & primary tumors & $5,375(96.6 \%)$ & $5,441(93.1 \%)$ & $5,413(87.7 \%)$ & $5,462(83.4 \%)$ \\
\hline & $\begin{array}{l}\text { subsequent multiple tumors developed } \\
\text { in already diagnosed cancer patients }\end{array}$ & $192(3.4 \%)$ & $403(6.9 \%)$ & $760(12.3 \%)$ & $1,089(16.6 \%)$ \\
\hline \multirow{2}{*}{$\begin{array}{l}\text { female breast } \\
\text { (C50) }\end{array}$} & primary tumors & $2,900(95.6 \%)$ & $3,756(91.8 \%)$ & $4,922(88.3 \%)$ & $5,479(85.2 \%)$ \\
\hline & $\begin{array}{l}\text { subsequent multiple tumors developed } \\
\text { in already diagnosed cancer patients }\end{array}$ & $133(4.4 \%)$ & $336(8.2 \%)$ & $652(11.7 \%)$ & $955(14.8 \%)$ \\
\hline \multirow{2}{*}{$\begin{array}{l}\text { uterine cervix } \\
\text { (C53) }\end{array}$} & primary tumors & $1,089(98.3 \%)$ & $1,099(96.6 \%)$ & 997 (94.3\%) & $937(92.1 \%)$ \\
\hline & $\begin{array}{l}\text { subsequent multiple tumors developed } \\
\text { in already diagnosed cancer patients }\end{array}$ & $19(1.7 \%)$ & $39(3.4 \%)$ & $60(5.7 \%)$ & 80 (7.9\%) \\
\hline \multirow{2}{*}{$\begin{array}{l}\text { corpus uteri } \\
\text { (C54) }\end{array}$} & primary tumors & 1,218 (97.2\%) & 1,399 (94.0\%) & 1,531 (89.9\%) & $1,660(88.5 \%)$ \\
\hline & $\begin{array}{l}\text { subsequent multiple tumors developed } \\
\text { in already diagnosed cancer patients }\end{array}$ & 35 (2.8\%) & $89(6.0 \%)$ & 172 (10.1\%) & 217 (11.5\%) \\
\hline \multirow[t]{2}{*}{ ovary (C56) } & primary tumors & 846 (95.4\%) & 966 (92.0\%) & 1,020 (87.7\%) & 941 (83.8\%) \\
\hline & $\begin{array}{l}\text { subsequent multiple tumors developed } \\
\text { in already diagnosed cancer patients }\end{array}$ & 41 (4.6\%) & 84 (8.0\%) & 143 (12.3\%) & $183(16.2 \%)$ \\
\hline \multirow[t]{2}{*}{ prostate (C61) } & primary tumors & $1,256(94.6 \%)$ & 1,842 (90.4\%) & 3,335 (85.8\%) & $5,462(85.7 \%)$ \\
\hline & $\begin{array}{l}\text { subsequent multiple tumors developed } \\
\text { in already diagnosed cancer patients }\end{array}$ & 72 (5.4\%) & 195 (9.6\%) & $551(14.2 \%)$ & 911 (14.3\%) \\
\hline \multirow[t]{2}{*}{ kidney (C64) } & primary tumors & 869 (94.6\%) & 1,692 (90.8\%) & $2,196(85.3 \%)$ & $2,354(80.5 \%)$ \\
\hline & $\begin{array}{l}\text { subsequent multiple tumors developed } \\
\text { in already diagnosed cancer patients }\end{array}$ & $50(5.4 \%)$ & 172 (9.2\%) & 377 (14.7\%) & 570 (19.5\%) \\
\hline \multirow[t]{2}{*}{ bladder (C67) } & primary tumors & 976 (95.3\%) & 1,402 (90.8\%) & $1,796(85.0 \%)$ & 1,776 (80.7\%) \\
\hline & $\begin{array}{l}\text { subsequent multiple tumors developed } \\
\text { in already diagnosed cancer patients }\end{array}$ & 48 (4.7\%) & 143 (9.2\%) & 317 (15.0\%) & 424 (19.3\%) \\
\hline
\end{tabular}

Problems with access to early diagnosis were observed in a regional survey presented in Tab. 9. Significant regional heterogeneity in early detection rate was found for nearly all listed diagnoses, including the most prevalent colorectal cancer (inter-regional range in proportion to early diagnosed cases: 42.0-52.3\%), prostate cancer (56.8$-78.9 \%)$, or bladder cancer (65.1-88.7\%). It should be mentioned that even the overall cancer burden significantly varies between different regions of the Czech Republic. Crude incidence for different regions estimated for the period 2007-2011 ranged from 499.8 to 637.1 , and crude mortality ranged from 237.4 to 281.6 (Tab. 9). Such heterogeneity cannot be explained solely by the fact that the population structure of the regions differs. In selected cancer types, the regional distribution of age-standardized incidence rather indicates the potential influence of some external, most probably environmental factors (Fig. 3).

\section{Discussion}

The cancer burden in the Czech population ranks among the highest worldwide and is growing continuously [4,6]. During the 1990s and 2000s, the incidence of all major cancers in the Czech population was constantly increasing [20] and the growth dynamic was consistent with recently published international 


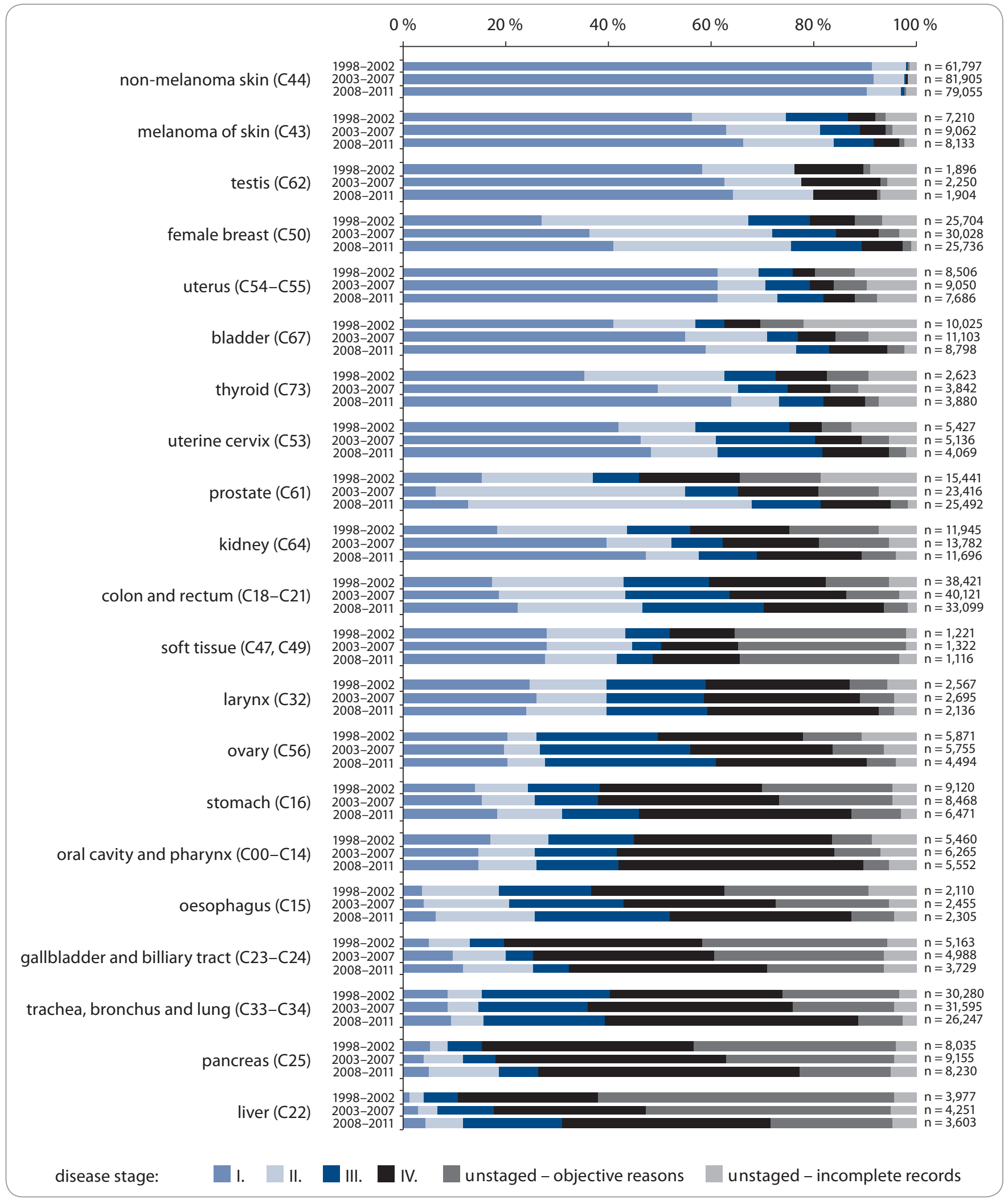

Fig. 2. Proportion of clinical stages in malignant disorders (sorted by proportion of stage I + II; Czech National Cancer Registry, 1998-2011).

data [1-5]. Furthermore, the relative profile of most prevalent cancer types (breast cancer in women, prostate cancer in men, colorectal and lung cancer in both genders) corresponds to the outcomes of recent European epidemiology summaries [1]. Lung cancer is the most frequent cause of death from cancer in both males and 
females, with annual death rates of 3,911 and 1,679, respectively.

The growing cancer burden trend can generally be attributed to widely known risk factors, such as apparent demographic aging of the Czech population, life style factors or, more specifically, to changes in reproductive behavior (e.g. for female breast cancer) [31].

Continuous cancer incidence growth can also be expected in the foreseeable future due to the demographic structure and aging of the Czech population. In 1999, the average age was 36.8 years for men and 40.0 years for women. Within 12 years, these values have shifted to 39.6 years for men and 42.5 years for women (data from 2011). During the period 1999-2011, the proportion of inhabitants aged over 50 years increased by $4.6 \%$.

The increasing incidence was also noted for preventable cancers, particularly colorectal carcinoma. The incidence of colorectal cancer in the Czech male population ranks $4^{\text {th }}$ highest in the world [2]. The growing incidence of colorectal cancer (growth index 2001-2011: 6.0\%) was accompanied by a relatively low rate of early detection of the disease (only $46.1 \%$ of incident cases in stage I or II). Furthermore, the relative rate of early detected cases varied greatly among regions (42.0-52.3\%), which indicates certain disparities in cancer control. These findings should guide further development of the Czech colorectal screening program $[32,33]$.

Based on the results of various international trials, a decrease in colorectal cancer mortality by more than 30\% due to organized screening based on annual faecal occult blood test (FOBT) can be expected [34,35]. However, recent Czech data indicate only $25.8 \%$ coverage of the target adult population by FOBT screening, which is insufficient to trigger substantial population changes. Therefore, a population-based program including invitation of the target population to cancer screening was initiated in January 2014 [33].

The recent situation of the epidemiology of breast cancer in the Czech female population is better compared to that of colorectal cancer. Although the incidence of breast carcinoma is significantly increasing (growth index 2001-2011:22.9\%), it is accompanied by a continuous increase in cases diagnosed at an early stage (according to recent data, $75.3 \%$ of cases are diagnosed in stage I or II). These positive changes are due to the increasing impact of the Czech national breast cancers screening program [36] which has already reached more than $50 \%$ coverage of the target female population (aged 45-69 years). Similarly, as a consequence of the widely used PSA test, we can see a growing incidence of early detected prostate cancer (Tab. 8, Fig. 2), although no organized screening for this type of cancer exists in the Czech Republic.

On the other hand, cervical cancer is one of the few cancer diagnoses with a decreasing incidence (Tab. 8). This is probably associated with cervical cancer screening, the third organized cancer screening program recommended for implementation in the EU [11]. Cervical cancer prevention through cytology examinations has been running in the Czech Republic for many years. An organized screening program, including accreditation of cytology laboratories and data monitoring through the cervical cancer screening registry, was initiated in the Czech Republic in 2008 [37].

The cancer burden in the Czech Republic has also been increasing due to a growing incidence of multiple primary malignancies diagnosed in the same patient. Although the registration of multiple tumors is considered by many authors as rather a complicated issue [38], the Czech cancer registry provides reliable data on multiple synchronous or metachronous malignancies. The CNCR database makes it possible to identify a specific patient; therefore, malignancies occurring in the same person can be identified accurately, whether in the same or another location. The chronological order of multiple malignancies can be assessed as well. Table 7 summarizes the overall data, demonstrating that multiple malignancies are relatively common, although the rate differs markedly for various types of first tumors. If non-melanoma skin cancers (C44) and malignant neoplasms of uncertain behavior (D37-D48) are not considered, the relative frequency of recurring malignancies ranges from $14 \%$ to $16 \%$, the overwhelming majority (89\%) of recurring malignancies belonging to a different diagnostic group than the first tumor. Second malignancy belonging to the same diagnostic group was more common in breast cancer (C50) and testicular cancer (C62). Further studies of the phenomenon of second primary tumors are warranted, as they might provide important insights into causal relationships between different types of cancer. Additionally, it represents an opportunity for prevention and improved targeting of already diagnosed and treated cancer patients.

Inter-regional differences in reporting to the cancer registry need to be considered when mapping the national cancer burden. Although we cannot exclude some degree of under-registration in some regions, it is highly probable that its real impact is limited, particularly in the recent period since 2000. This assumption is based on regional profiles of mortality rates which fully correspond to those observed for incidence profiles. Mortality estimates in the Czech Republic are double-checked using two independent sources of information on death events, i.e. the cancer registry and the Death Records Database, are used $[18,19]$. The CNCR management follows the administrative division of the country into 14 regions and data are collected in the same manner in each of them. Moreover, the observed regional differences in the cancer burden are different for various cancers and do not reveal any consistent pattern (Fig. 3).

Therefore, in the light of regional differences (Tab. 9, Fig. 3), we cannot ignore the possible influence of environmental factors, although their contribution to the etiology of different types of human cancer has been disputed in the literature $[39,40]$. Czech adults in the risk age categories of 50-60 years or older were probably at least partially exposed to relatively 
Tab. 8. Classification of malignant neoplasms in the Czech Republic according to trends in incidence rates and clinical stage at the time of diagnosis.

\section{Classification according to trends in incidence rates}

\begin{tabular}{l|l|l}
$\begin{array}{l}\text { diagnoses of malignant tumors with } \\
\text { raising incidence rates }\end{array}$ & $\begin{array}{l}\text { diagnoses of malignant tumors with } \\
\text { stabilized incidence rates }\end{array}$ & $\begin{array}{l}\text { diagnoses of malignant tumors with } \\
\text { decreasing incidence rates }\end{array}$ \\
\hline $\mathrm{C} 61(\mathrm{Gl}:+115.3 \%)$ & $\mathrm{C} 91-\mathrm{C} 95(\mathrm{Gl}:+8.0 \%)$ & $\mathrm{C} 81(\mathrm{Gl}:-6.4 \%)$ \\
\hline $\mathrm{C} 73(\mathrm{Gl}:+81.2 \%)$ & $\mathrm{C} 67(\mathrm{Gl}:+7.6 \%)$ & $\mathrm{C} 53(\mathrm{Gl}:-7.5 \%)$ \\
\hline $\mathrm{C} 44(\mathrm{Gl}:+60.7 \%)$ & $\mathrm{C} 18-\mathrm{C} 21(\mathrm{Gl}:+6.0 \%)$ & $\mathrm{C} 23, \mathrm{C} 24(\mathrm{Gl}:-11.9 \%)$ \\
\hline $\mathrm{C} 43(\mathrm{Gl}:+41.1 \%)$ & $\mathrm{C} 33, \mathrm{C} 34(\mathrm{Gl}:+5.7 \%)$ & $\mathrm{C} 16(\mathrm{Gl}:-14.0 \%)$ \\
\hline $\mathrm{C} 15(\mathrm{Gl}:+40.4 \%)$ & $\mathrm{C} 32(\mathrm{Gl}:+1.0 \%)$ & \\
\hline $\mathrm{C} 25(\mathrm{Gl}:+29.5 \%)$ & & \\
\hline $\mathrm{C} 82-85, \mathrm{C} 96(\mathrm{Gl}:+23.2 \%)$ & & \\
\hline $\mathrm{C} 50(\mathrm{Gl}:+22.9 \%)$ & & \\
\hline $\mathrm{C} 64(\mathrm{Gl}:+22.0 \%)$ & & \\
\hline $\mathrm{C} 00-\mathrm{C} 14(\mathrm{Gl}:+21.7 \%)$ & & \\
\hline $\mathrm{C} 62(\mathrm{Gl}:+21.4 \%)$ & & \\
\hline $\mathrm{C} 47, \mathrm{C} 49(\mathrm{Gl}:+17.2 \%)$ & & \\
\hline $\mathrm{C} 70-\mathrm{C} 72(\mathrm{Gl}:+14.4 \%)$ & & \\
\hline $\mathrm{C} 22(\mathrm{Gl}:+13.3 \%)$ & & \\
\hline $\mathrm{C} 54, \mathrm{C} 55(\mathrm{Gl}:+12.4 \%)$ & & \\
\hline $\mathrm{C} 90(\mathrm{Gl}:+10.0 \%)$ & & \\
\hline
\end{tabular}

Classification according to detection rates of less advanced stages of malignant tumors

low detection rates at stages I and II

C25 (SI+ II: 17.7\%)

C33, C34 (SI + II: 15.4\%)

C22 (SI+ II: $11.0 \%)$

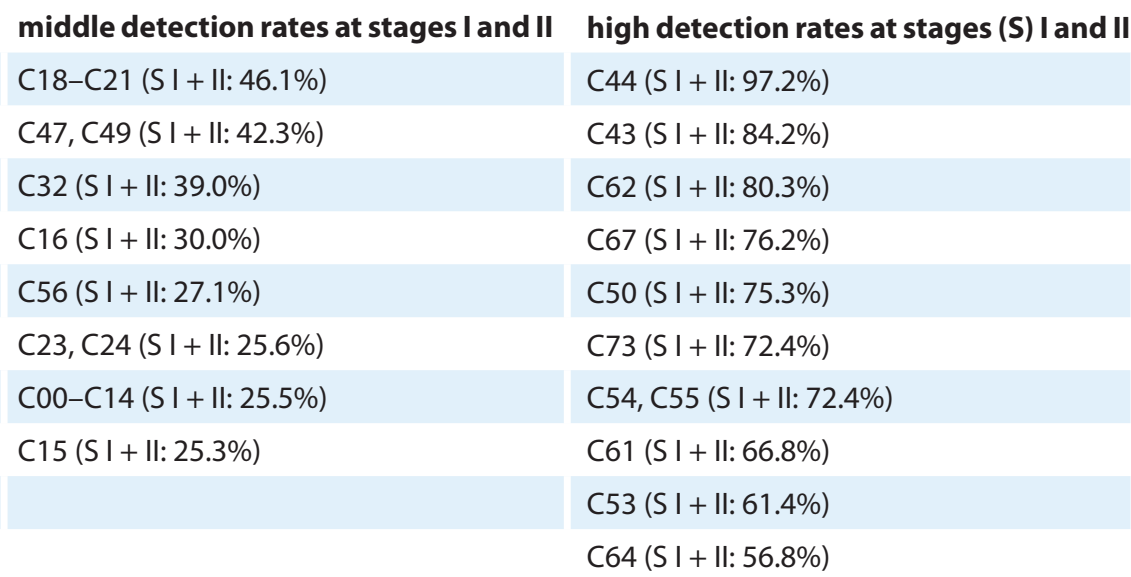

C00-C14 - oral cavity and pharynx, C15 - oesophagus, C16 - stomach, C18-C21 - colon and rectum, C22 - liver and intrahepatic bile ducts, C23, C24 - gallbladder and biliary tract, C25 - pancreas, C32 - pharynx, C33, C34 - trachea, bronchus and lung, C43 - skin melanoma, C44 - other malignant neoplasm of the skin, C47, C49 - connective and soft tissue, C50 - breast (women), C53 - cervix uteri, C54, C55 - uterus, C56 - ovary, C61 - prostate, C62 - testis, C64 - kidney, C67 - bladder, C70-C72 - brain and spinal cord, C73 - thyroid gland, C81 - Hodgkin lymphoma, C82-C85, C96 - non-Hodgkin lymphoma, C90 - multiple myeloma, C91-C95 - leukaemia, GI - growth index related to the period 2001-2011, S I + II - proportion of clinical stages I + II in the overall incidence of the disease, data from period 2007-2011

high concentrations of environmental pollutants, including polychlorinated biphenyls (PCBs), DDT and other pesticides in the 1960s-1970s [6]. This exposure, however, cannot be quantified precisely due to the lack of environmental data from the period of Communist government before 1989. Although we cannot address the role of 


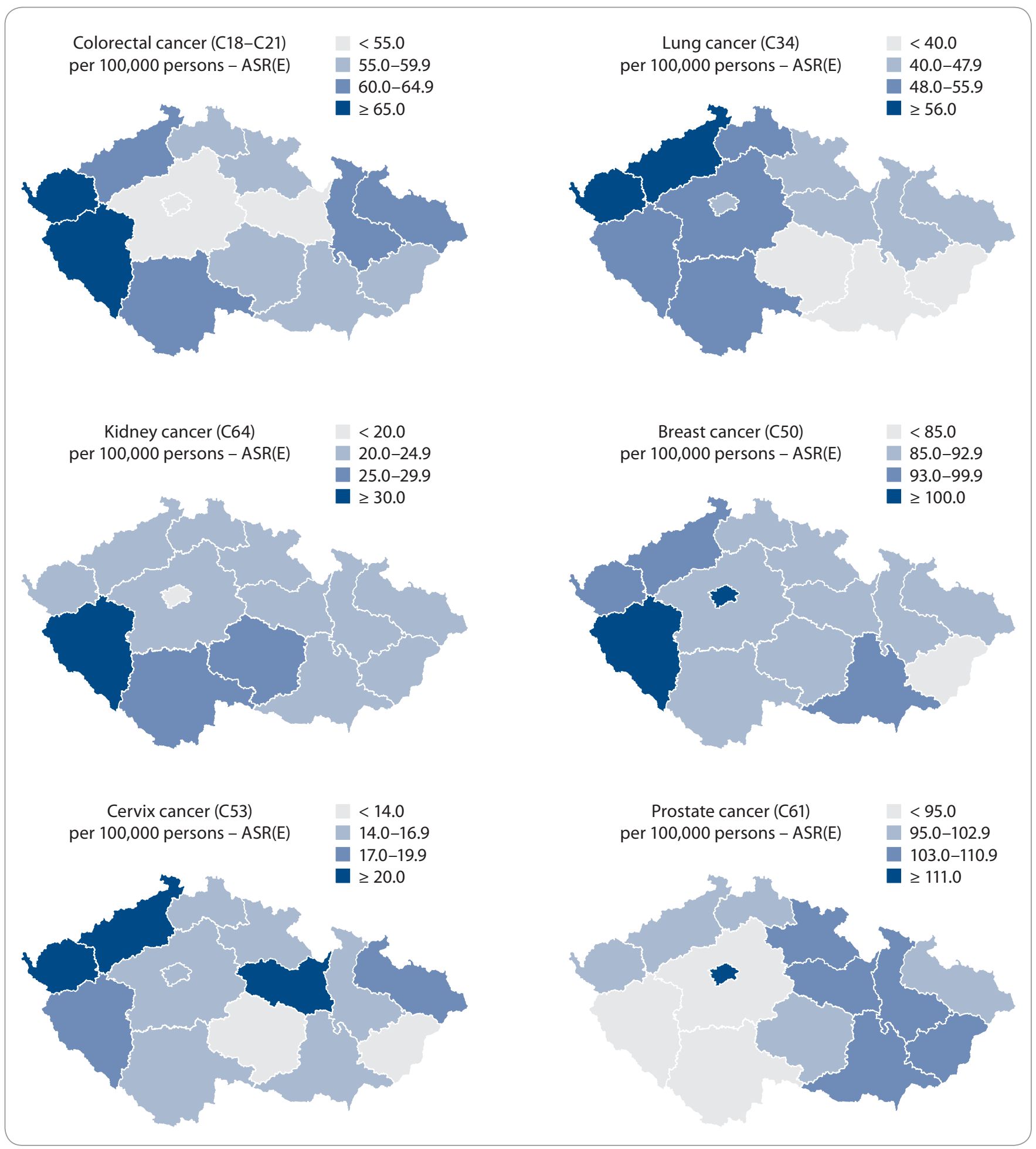

Fig. 3A. Examples of regional differences in cancer incidence in period 2007-2011 (selected most frequent cancers, Czech National Cancer Registry).

the environment in cancer causation, some birth-cohort effects should be studied as an indirect population indicator of unspecified harmful effects in the past. This information should be translated in well-designed future studies focused on the space variability of cancer epidemiology in the Czech Republic.

The present analysis is based on 34 years of experience of a nationwide, fully representative cancer registry. It supports the idea that cancer registries can be accepted as one of the main sources for improvement of our understanding of cancer and its 


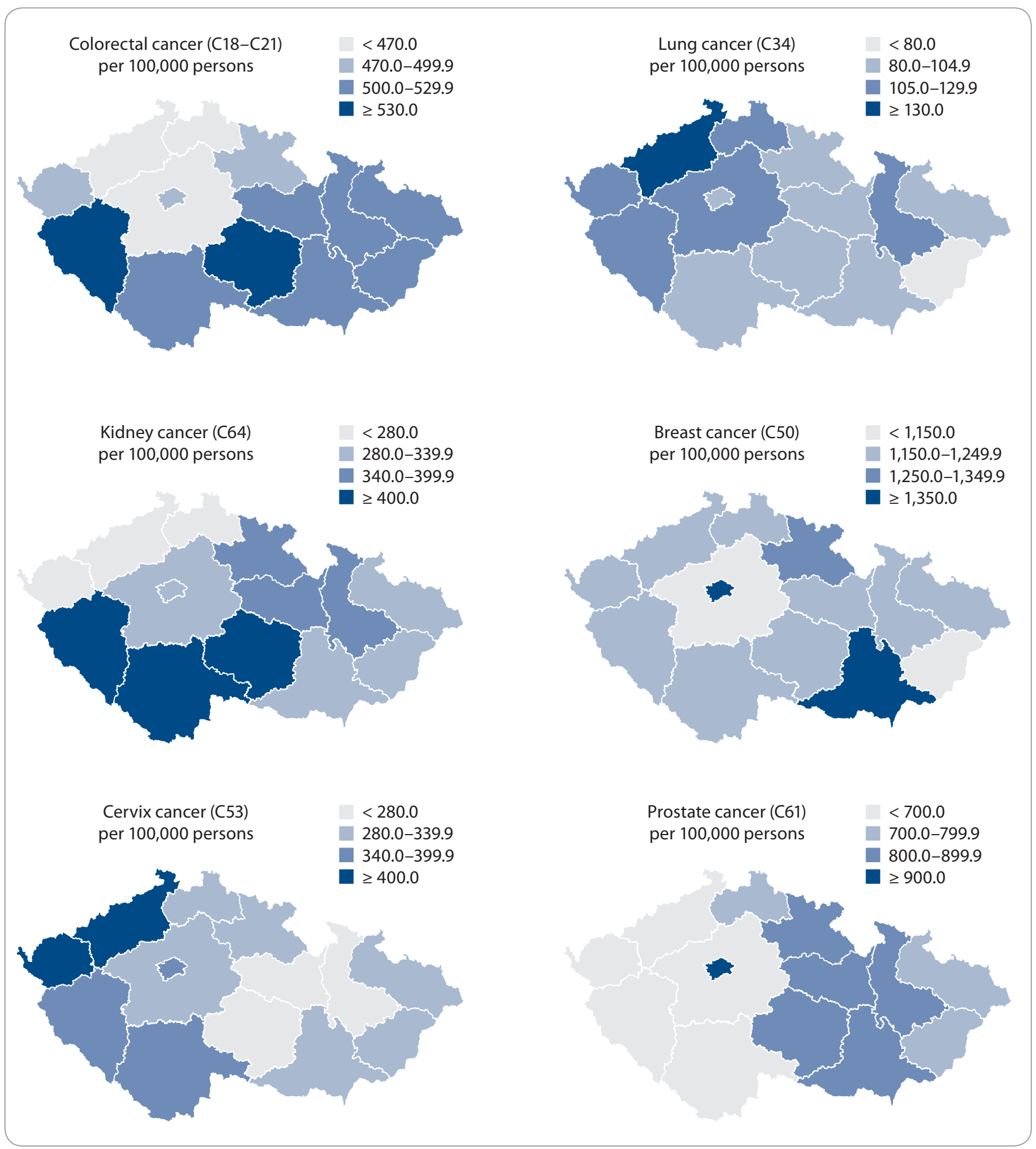

Fig. 3B. Examples of regional differences in cancer prevalence, end of year 2011 (selected most frequent cancers, Czech National Cancer Registry).

causation. Representative registries may reveal factors that are underlying trends in cancer incidence; moreover, they can detect significant changes over time in the main diagnostic parameters (such as morphology and staging). This information is necessary to promote prevention which might ultimately lead to better control of the disease. The CNCR contains complete and comprehensive records on the clinical stage at the time of diagnosis, including detailed records on individual components of TNM classification. The overall CNCR assessment has revealed only $3.8 \%$ of 
Tab. 9. Regional differences in the main epidemiological trends of malignant neoplasms excluding non-melanoma skin cancer (C00-C97 excluding C44) in the Czech Republic. Mortality statistics - Czech Statistical Office.

\begin{tabular}{|c|c|c|c|}
\hline Indicator & $\begin{array}{l}\text { Data from } \\
\text { period }\end{array}$ & $\begin{array}{l}\text { Average value over } \\
\text { the whole population }\end{array}$ & $\begin{array}{l}\text { Range of values in regions } \\
\text { (min.; max.; } n=14 \text { regions) }\end{array}$ \\
\hline incidence rate per 100,000 population & 2007-2011 & 533.2 & $(499.8 ; 637.1)$ \\
\hline age standardized incidence rate, $A S R(E)$ & 2007-2011 & 415.1 & $(384.5 ; 484.3)$ \\
\hline incidence growth index related to 2001 & $2001-2011$ & $18.9 \%$ & $(9.6 \% ; 35.4 \%)$ \\
\hline mortality rate per 100,000 population & $2007-2011$ & 261.4 & $(237.4 ; 281.6)$ \\
\hline age standardized mortality rate, $\mathrm{ASR}(\mathrm{E})$ & $2007-2011$ & 193.8 & $(172.6 ; 224.8)$ \\
\hline mortality growth index related to 2001 & $2001-2011$ & $-5.1 \%$ & $(-14.0 \% ; 4.8 \%)$ \\
\hline prevalence rate per 100,000 population & 2011 & 3,308 & $(2,986 ; 3,629)$ \\
\hline prevalence growth index related to 2001 & $2001-2011$ & $57.5 \%$ & $(42.9 \% ; 69.7 \%)$ \\
\hline mortality/incidence index & $2007-2011$ & 0.49 & $(0.44 ; 0.54)$ \\
\hline $\begin{array}{l}\text { selected diagnostic groups: detection rate at clinical } \\
\text { stages I + II }\end{array}$ & $2007-2011$ & & \\
\hline stomach (C16) & & $30.0 \%$ & $(23.5 \% ; 38.7 \%)$ \\
\hline colon and rectum (C18-C21) & & $46.1 \%$ & $(42.0 \% ; 52.3 \%)$ \\
\hline pancreas (C25) & & $17.7 \%$ & $(11.5 \% ; 25.3 \%)$ \\
\hline trachea, bronchus and lung (C33, C34) & & $15.4 \%$ & $(12.4 \% ; 19.7 \%)$ \\
\hline skin melanoma (C43) & & $84.2 \%$ & $(74.3 \% ; 90.2 \%)$ \\
\hline breast - women (C50) & & $75.3 \%$ & $(72.3 \% ; 79.3 \%)$ \\
\hline uterus (C54, C55) & & $72.4 \%$ & (60.5\%; 86.3\%) \\
\hline prostate (C61) & & $66.8 \%$ & $(56.8 \% ; 78.9 \%)$ \\
\hline kidney (C64) & & $56.8 \%$ & $(47.7 \% ; 62.7 \%)$ \\
\hline bladder (C67) & & $76.2 \%$ & (65.1\%; 88.7\%) \\
\hline $\begin{array}{l}\text { proportion of cancer detection during autopsy } \\
\text { and from DCO }\end{array}$ & 2007-2011 & $3.8 \%$ & $(1.2 \% ; 6.2 \%)$ \\
\hline
\end{tabular}

records which are missing information on both TNM classification and clinical stage in an unexplained manner (Fig. 2). The completeness of CNCR data increases with time, and the most recent period (2000-2011) provides high-quality data. The CNCR is equipped with a web-based analytic tool which allows any user to perform comprehensive analyses in a user-friendly environment [20]. We regard the CNCR database and associated software as one of the strongest points of the Czech National Cancer Control Program, providing a basis for international collaborative efforts [41].

\section{Conclusion}

Using the available epidemiologic data, the cancer burden in the Czech Republic can be assessed throughout the population and for individual regions. The proportion of clinical stages as well as the success rate of early detection can be analyzed and the time trends calculated based on available data. The strongest point of the present study lies in the accessibility of information over a 34-year period of continuous and standardized registration covering virtually 100\% of cancer diagnoses within the entire Czech population. The data summary is also available as a public on-line interactive tool [20]. The main challenge for the future is to use these tools to contribute to the reduction of cancer mortality, particularly by decreasing the proportion of late-stage diagnoses and addressing the remarkable regional differences in diagnostic efficacy.

\section{References}

1. Ferlay J, Steliarova-Foucher E, Lortet-Tieulent J et al, Cancer incidence and mortality patterns in Europe: estimates for 40 countries in 2012. Eur J Cancer 2013; 49(6): 1374-1403. doi: 10.1016/j.ejca.2012.12.027.

2. Ferlay J, Soerjomataram I, Ervik M et al. GLOBOCAN 2012 v1.0, Cancer Incidence and Mortality Worldwide: IARC CancerBase No. 11 [Internet]. Lyon, France: International Agency for Research on Cancer; 2013 [cited 6 May 2014]. Available from: http://globocan.iarc.fr.

3. Boyle P, Ferlay J. Cancer incidence and mortality in Europe, 2004. Ann Oncol 2005; 16(3): 481-488.

4. Curado MP, Edwards B, Shin HR et al (eds). Cancer Incidence in Five Continents, Vol. IX. IARC Scientific Publications No. 160 [Internet]. Lyon: IARC; 2007 [cited 8 May 2013]. Available from: http://ci5.iarc.fr.

5. Ferlay J, Parkin DM, Steliarova-Foucher E. Estimates of cancer incidence and mortality in Europe in 2008. Eur J Cancer 2010; 46(4): 765-781.

6. Dušek L (ed.). Czech cancer care in numbers 2008-2009. Praha: Grada Publishing 2009.

7. Franco EL, Correa P, Santella RM et al. Role and limitations of epidemiology in establishing a causal association. Semin Cancer Biol 2004; 14(6): 413-426.

8. De Angelis R, Sant M, Coleman MP et al. Cancer survival in Europe 1999-2007 by country and age: results of 
EUROCARE-5 - a population-based study. Lancet Oncol 2014: 15(1): 23-34. doi: 10.1016/S1470-2045(13)70546-1. 9. Pavlik T, Majek O, Büchler T et al. Trends in stage-specific population-based survival of cancer patients in the Czech Republic in the period 2000-2008. Cancer Epidemiol 2014; 38(1): 28-34. doi: 10.1016/j.canep.2013.11.002. 10. de Leon MP, Rossi G, di Gregorio C et al. Epidemiology of colorectal cancer: the 21-year experience of a specialised registry. Intern Emerg Med 2007; 2(4): 269-279.

11. Council of the European Union. Council recommendation of 2 December 2003 on cancer screening (2003/878/EC). Official Journal of the European Union 2003: L 327/34: 85-89.

12. IARC Working Group on the Evaluation of Cancer-Preventive Strategies. IARC Handbooks of Cancer Prevention Vol. 10. Cervix Cancer Screening. Lyon: IARC Press 2005. 13. Perry N, Broeders M, de Wolf C et al (eds). European guidelines for quality assurance in breast cancer screening and diagnosis. 4th ed. Luxembourg: Office for Official Publications of the European Communities 2006.

14. Segnan N, Patnick J, von Karsa L (eds). European guidelines for quality assurance in colorectal cancer screening and diagnosis. Luxembourg: Publications Office of the European Union 2010

15. Arbyn M, Anttila A, Jordan J et al (eds). European guidelines for quality assurance in cervical cancer screening. 2nd ed. Luxembourg: Office for Official Publications of the European Communities 2008

16. Bray F, Sankila R, Ferlay J et al. Estimates of cancer incidence and mortality in Europe in 1995. Eur J Cancer 2002; 38(1): 99-166.

17. Czech Statistical Office. Demographic data of the Czech Republic and Death Records Database of the Czech Republic [cited 8 May 2014]. Available from: http://www. czso.cz/eng/redakce.nsf/i/population.

18. Czech Statistical Office. Demographic Yearbook of the Czech Republic 2011 [cited 8 May 2014]. Available from: http://www.czso.cz.

19. Institute of Health Information and Statistics of the Czech Republic (IHIS). National Health Information System (NHIS), Czech National Cancer Registry [cited 2014 May 8]. Available from: http://www.uzis.cz/registry-nzis/nor.
20. Dušek L, Mužík J, Kubásek M et al. Epidemiology of malignant tumors in the Czech Republic [Internet]. Brno: Masaryk University 2005 [cited 8 May 2014]. Available from: http://www.svod.cz

21. Institute of Health Information and Statistics of the Czech Republic (IHIS). Binding instructions of the National Health Information System (NHIS): Czech National Cance Registry - instruction for the contents of data structure, version 010-20140101. Prague: IHIS [cited 5 May 2014]. Available from: http://www.uzis.cz/registry-nzis/nor.

22. World Health Organization. International statistica classification of diseases and related health problems, 10th revision (ICD-10). Geneva: World Health Organization 1992

23. World Health Organization. International classification of diseases for oncology (ICD-O, third revision). Geneva: World Health Organization 2000

24. Sobin LH, Gospodarowicz MK, Wittekind Ch (eds). TNM classification of malignant tumors. 7th ed. Oxford: Wiley-Blackwell 2009

25. World Health Organization. WHO Statistical Information System [Internet]. Geneva: WHO Databank [cited 8 May 2014]. Available from: http://www.who.int/whosis. 26. Jougla $E$ (ed.). Comparability and quality improvement of European causes of death statistics, EDC DGV/F3 SOC 98 20108-INSERM SC8/Cepidc-Final Report. July 2001.

27. Percy $C$, Muir $C$. The international comparability of cancer mortality data. Results of an international death certificate study Am J Epidemiol 1989: 129(5): 934-946. 28. Waterhouse J, Muir CS, Shanmugaratnam K et al (eds). Cancer incidence in five continents, Vol. IV. IARC Scientific Publications No. 42. Lyon: IARC 1982.

29. Adami HO, Hunter D, Trichopoulos D (eds). Textbook of cancer epidemiology. New York: Oxford University Press 2002

30. Waterhouse J, Muir CS, Correa P et al (eds). Cancer in cidence in five continents, Vol. III. IARC Scientific Publications No. 15. Lyon: IARC 1976.

31. Karim-Kos HE, de Vries E, Soerjomataram I et al. Recent trends of cancer in Europe: a combined approach of incidence, survival and mortality for 17 cancer sites since the 1990s. Eur J Cancer 2008; 44(10): 1345-1389.
32. Suchanek S, Majek O, Vojtechova G et al. Colorectal cancer prevention in the Czech Republic: time trends in performance indicators and current situation after 10 years of screening. Eur $J$ Cancer Prev 2014; 23(1): 18-26. doi: 10.1097/CEJ.0b013e328364 f203.

33. Zavoral M, Suchanek S, Majek O et al. Colorectal cancer screening: 20 years of development and recent progress. World J Gastroenterol 2014; 20(14): 3825-3834. doi: 10.3748/wjg.v20.i14.3825

34. Mandel JS, Bond JH, Church TR et al. Reducing mortality from colorectal cancer by screening for fecal occult blood. Minnesota Colon Cancer Control Study. N Engl J Med 1993; 328(19): 1365-1371

35. Hardcastle JD, Chamberlain JO, Robinson MH et al. Randomised controlled trial of faecal-occult-blood screening for colorectal cancer. Lancet 1996; 348(9040): 1472-1477.

36. Majek O, Danes J, Skovajsova M et al. Breast cancer screening in the Czech Republic: time trends in performance indicators during the first seven years of the organised programme. BMC Public Health 2011; 11: 288 37. Majek O, Danes J, Zavoral M et al. Czech National Cancer Screening Programmes in 2010. Klin Onkol 2010; 23(5): 343-353.

38. Flannery JT, Boice JD Jr, Devesa SS et al. Cancer registration in Connecticut and the study of multiple primary cancers, 1935-82. Natl Cancer Inst Monogr 1985; 68: 13-24.

39. Boffetta P, McLaughlin JK, La Vecchia C et al. 'Environment' in cancer causation and etiological fraction: limitations and ambiquities. Carcinogenesis 2007; 28(5): 913-915

40. Wild CP. Environmental exposure measurement in cancer epidemiology. Mutagenesis 2009; 24(2): 117-125. doi: 10.1093/mutage/gen061

41. Engholm G, Ferlay J, Christensen N et al. NORDCAN: Cancer Incidence, Mortality, Prevalence and Survival in the Nordic Countries, Version 6.1 [Internet]. Association of the Nordic Cancer Registries. Danish Cancer Society, 2014 [cited 8 May 2014]. Available from: http://www.ancr.nu.

\title{
Informace z České onkologické společnosti
}

\author{
Zápisy ze schůzí výboru České onkologické společnosti konaných dne 17. 10. 2014 v Českém Krumlově a dne 21. 10. 2014 v Brně \\ naleznete na www.linkos.cz
}

